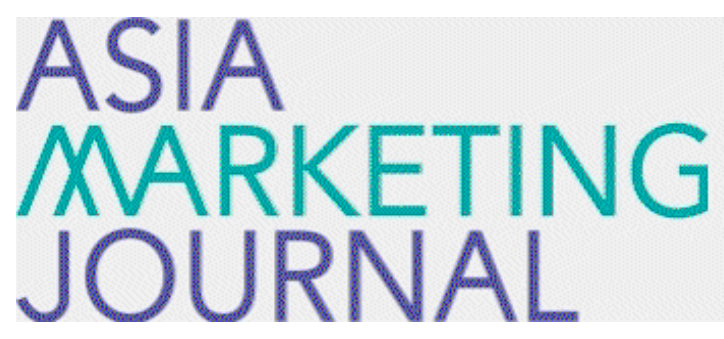

ASIA MARKETING JOURNAL

Volume 7 | Issue 3

Article 4

10-27-2005

\title{
디지털 인프라를 활용하는 Interactive Marketing 시대가 왔다
}

Jong Won Lim

Follow this and additional works at: https://amj.kma.re.kr/journal

Part of the Marketing Commons

\section{Recommended Citation}

Lim, Jong Won (2005) "디지털 인프라를 활룡하는 Interactive Marketing 시대가 왔다," Asia Marketing Journal: Vol. 7 : Iss. 3 , Article 4.

Available at: https://doi.org/10.53728/2765-6500.1151

This Article is brought to you for free and open access by Asia Marketing Journal. It has been accepted for inclusion in Asia Marketing Journal by an authorized editor of Asia Marketing Journal. 


\title{
디지털 인프라를 활용하는 Interactive Marketing 시대가 왔다*
}

\author{
The Coming Age of Interactive Marketing \\ Based on Digital Infrastructure*
}

임 종 원(Lim, Jong Won) ${ }^{* *}$

본 글은 한국마케팅저널 편집규정 2조 4항에 근거하여 원로회원에게 청탁한 것입니다. 2조 4항: 열 린마당(open plaza)은 book review, issue, short essay 등을 다루며 A4 4-5장 정도의 분량으로 편집 위원회에서 원로회원 및 특정 회원에게 원고를 청탁할 수 있다.

마케팅의 핵심요소는 고객과 공급자와의 관 계, 고객 상호간의 관계, 그리고 고객의 문제에 대한 해결 방안을 제공하는 공급자들 상호관계, 그리고 마케팅 환경요소들과의 관계관리라고 할 수 있다. 이러한 관계 관리의 수단으로서 자 본적 수단과 인적 수단을 사용하였다.

마케팅 시스템의 구성요소와의 연결 관계를 주도한 것은 공급자이었다.

그러나 디지털 인프라가 보편화됨에 따라 연 결의 범위와 빈도가 확대되고 있다. 언제 어디 서나 음성, 문자, 그리고 동영상이 복합화된 상 태로 풍부한 정보를 상호 실시간으로 교환할 수 있는 시대가 되었다. 특히 과거의 일방적 방 향의 커뮤니케이션에서 이제는 고객의 요구(On Demand)에 즉시 반응하는 상호작용이 마케팅
네트워크에서 동시적으로 복합적으로 이루어지 게 되었다. 고속 인터넷을 휴대폰이나 컴퓨터 그리고 케이블 TV, 디지털 TV로 이용하는 인 구가 증가하고 있다. 케이블 TV를 이용하는 홈쇼핑업태가 백화점, 할인점과 경쟁하고 있다. 금융, 증권, 보험업계도 온라인 유통의 비중이 증가하고 비수익 점포들을 통폐합하고 있다. 승 용차와 같은 내구성 제품의 경우에도 온라인망 을 효율적으로 이용하는 점포는 전국으로부터 주문을 받고 있다. 전통적인 상권관리의 의미는 사라지고 있다. 음악을 즐기기 위해서 $\mathrm{CD}$ 나 테 이프를 구입하는 시대도 사라져 버렸다.

디지털 인프라는 소비자의 행동을 바꾸었다. 공급자들도 디지털 인프라를 빠르게 적용하지 못하면 시장에서 사라지고 있다. 막대한 투자를

* 본 연구는 서울대학교 경영연구소의 지원으로 작성되었습니다.

** 서울대학교 경영대 교수(jim@snu.ac.kr) 
하여 개점하는 할인점의 운명도 불안하게 되었 다. 새로운 비즈니스 모델의 성장과 몰락이 계 속되고 있다. 새로운 휴대폰이 계절마다 나타나 고 신제품의 매출커브는 완곡한 $\mathrm{S}$ 형 커브가 아 니라 2차함수 곡선을 그리며 성장하다 곧 사라 져 버리는 새로운 형태의 매출 곡선을 그리고 있다. 모든 것이 변화하고 있다. 마케팅 교과서 도 디지털 인프라를 활용하면 마케팅이 어떻게 변화하게 되는가를 밝혀야 할 것이다.

\section{I. 소비자 행동이 가상공간에서도 할성화되고 있다.}

\section{1 상물 분리의 보편화}

디지털 환경이 보편화됨에 따라 소비자행동도 많은 변화를 일으키고 있다. 상적활동과 물적 활동의 분리현상이 나타났다. 백화점이나 할인 점과 같이 매매와 동시에 구매자가 상품을 인 수하여 가져가는 상거래보다 매매는 online에서 그리고 배송은 전문 택배회사에서 수행하는 경 우가 늘어나고 있다.

\section{2 커뮤니티 활동의 생활화}

600 여개의 자동차 동호회가 활동하고 있으며 이 중에서 160 개의 동호회가 '카메이니어(carmania)' 라는 연합회를 만들어 활동하고 있다. 자동차의 opinion leader들이 모여 어떤 할동을 하는가를 정확하게 파악할 수 있게 되었다. 신제품의 장 단점이 무엇인지에 대한 정보를 얻고자 한다면 carmanianet을 찾아가 물어 보면 된다. 신문이 나 잡지의 광고보다 더 신뢰성이 있는 정보를 쉽 게 얻을 수 있게 되었다. 인터넷과 컴퓨터 그리 고 휴대폰으로 연결되는 사회(intemet mediated community)가 발전하고 있다. 디지털 카메라를 30 만원 정도의 예산으로 구입하려고 하는 소비 자는 누구에게 물어보면 가장 신속하게 정확한 정보를 얻을 수 있을까?

\section{3 소비자의 마케팅 참여 증가}

셀프 서비스(self service)라는 말이 있다. 종 업원으로부터 서비스를 받고 그 대가를 지불하 지 말고 고객이 스스로 서비스한다는 의미이다. 뷔페식당, 할인점, 슈퍼마켓에서는 고객이 스스 로 원하는 것을 선택할 수 있다. 종업원의 인건 비가 절약되는 만큼 가격도 할인받게 되어 있 다. 이와 같이 소비자가 마케팅 활동에 참여하 게 되면 공급자는 품질을 높이거나 원가를 절 감할 수 있게 하여 준다. 소비자가 상품의 구매 가격을 인하하여 실질소득을 증가시키기 위하 여 다음과 같은 마케팅 기능에 참여하여 왔다. 오늘날 소비자들은 디지털 환경을 이용하여 더 쉽게 더 광범위하게 마케팅 활동에 참여하고 있다.

$\triangleright$ 고객의 구매참여: 다양한 식당에 관한 정 보를 제공하는 정보 중간상(infomediary) 들이 있다. 2 만원대의 한식을 원하는 장소 주변에 어떤 식당이 있는 가에 대한 정보 와 예약까지 십게 할 수 있다. 메뉴와 고 객 수까지 확정하여 예약한다면 미리 미 리 식사 준비를 하여 고객이 도착하면 즉 
시 서비스를 제공할 것이다. 항공여행의 경우에도 고객이 스스로 여행일정을 제시 하면 항공사는 제휴 호텔에 관한 정보까 지 제공하기도 한다. 항공사는 고객들이 쉽게 여행상품을 미리 미리 구입할 수 있 도록 여행정보망을 운영하고 있다. 케이블 TV망을 이용하여 주문을 받는 홈쇼핑 업 계도 빠르게 성장하고 있다. 디지털 TV가 양방향 서비스를 제공하게 되면 고객이 요구하는 즉시(On Demand) 고객에게 상 품과 서비스를 제시하는 업태가 발전할 것이다. 의류 전문점에서는 단골고객의 의 류 소유 상황에 대한 정보를 가지고 있다. 고객이 스타일과 색상을 선택하면 고객에 게 맞는 사이즈의 상품을 집으로 배달까 지 하는 경우도 있다. 고객이 쉽게 빨리 구매에 참여할 수 있는 마케팅 프로그램 을 고객들은 선호하고 있다.

$D$ 고객의 생산참여: DIY(Do-It-Yourself) 제품을 이용하는 고객을 Prosumer라고 한다. 고객이 생산에 참여하는 대가로 가 격을 인하하여 판매하는 제품이 다양하게 증가하고 있다. 전자렌지가 보급되자 각 종 음식을 고객이 쉽게 빨리 준비할 수 있도록 도와주는 제품이 다양하게 개발되 고 있다. 고객이 자녀들과 함께 가구를 만들 수 있도록 분해된 제품을 전문적으 로 개발한 전문할인점(IKEA)도 있다.

$D$ 고객의 물류기능 참여: 가정마다 대형 냉 장고와 자가용 승용차를 보유하게 되자 고 객이 장기간 사용할 수 있는 대량 포장된 제품을 할인가격으로 판매하고 있다. 이러 한 제품을 자기 자동차로 운반한 다음 냉
장고에 저장하여 사용하려 한다면 운송기 능과 저장기능에 참여한다고 할 수 있다.

$D$ 고객의 시장정보 참여: 공급자에게 필요 한 정보를 미리 제공하는 고객도 있다. 선 호하는 상표가 무엇이며 또 선호하는 이 유, 예상 구매량과 예상 구매 시기를 공급 자에게 정확하게 알려주는 경우도 있다. 자동차 제조공장은 생산정보와 생산현황 을 실시간으로 부품공급자들에게 온라인 으로 제공한다. 이와 같은 정보를 공유함 으로써 부품업체는 생산에 차질이 없도록 조립현장에 배달 할 수 있게 된다. 소비자 들이 가상공간에 공동체를 만들고 입소문 (word-of-mouth)을 통하여 상호간에 정 보교환을 하면서 다양한 마케팅 정보가 신속하게 집적되고 선뼐되고 평가되면서 정보의 공유와 확산이 이루어지고 있다.

$D$ 고객의 시장금융참여: 골프장에는 몇 억 원을 지불하여야 구입할 수 있는 회원권 제도가 있다. 5 억 회원권을 100 명이 구입 하여 준다면 500 억원의 자금이 조달된다. 500 억원으로 멋있는 골프클럽을 만들 수 있을 것이다. 은행에서 차입한다면 금리를 지급하여야 한다. 그러나 소비자로부터 금 응을 받으면 이자를 지급할 필요가 없다.

$\triangleright$ 고객의 시장위험 참여: 인터넷 쇼핑의 경 우 신용카드 번호를 알려주고 제품이 배달 되기 전에 결제하게 된다. 소비자들은 여 러 가지의 위험을 부담하는 대가로 저가격 의 혜택을 얻게 된다.

인터넷이 컴퓨터뿐만 아니라 휴대폰으로도 이 용됨에 따라 소비자들이 적극적으로 마케팅에 
참여하면서 산업의 장벽이 무너지고 있다. 소비 자들이 커뮤니티를 형성하여 제품평가는 물론 수요를 조직화하여 가장 소비자에게 유리한 공 급자들을 선택하는 시대가 되었다. 텔레비전 프 로그램도 고객이 원하는 프로그램을 다운받아 원하는 시간, 원하는 장소에서 즐길 수 있는 시 대가 되었다. 고객과 실시간으로 상호작용할 수 있는 능력을 개발하여야 한다.

\section{Interactive Marketing과 $4 \mathrm{P}$ 요소의 변화}

\section{1 당연품질보다 환상적 품질을 요구한다.}

“언제 어디서나 통화품질이 좋다"라는 메시지 는 휴대폰으로서는 당연한 품질요소이다. 그러 나 디지털 카메라로 영상을 찍어 전달한다면 소비자들로서는 놀라운 일이다. 혼자서 사용하 는 제품이 아니라 우리들이 사용하는 제품이다. 한사람이 메시지를 전달하면 상대방은 즉시 반 응을 전하여 준다. $\mathrm{PC}$ (개인용 컴퓨터)도 정보 단말기로 보편화되었다. 언제 어디서나 상호의 사소통을 할 수 있는 기능이 있다. 우리들의 수 가 많을수록 네트워크 효과가 증가한다. 통신제 품의 경우 이제는 동영상도 해설 자료를 첨가 하여 상호 전달할 수 있다. 디지털 컨버젼스 (digital convergence)를 구현하는 복합상품과 융합서비스는 소비자들이 전혀 생각하지도 않 았던 품질, 소비자를 놀라게 하는 품질(wow quality), 즉 환상적 품질(fantastic quality)을 제공하고 있다.

\subsection{Orderless Order Delivery시대가 왔다.}

자동차의 판매정보는 즉시 조립공장과 연결되 어 생산계획에 반영된다. 조립공장의 생산계획 은 부품업체의 생산과 배송과 연결되어 있다. 모기업의 주문이 없더라도 조립공장의 생산라 인에 부품이 배달되도록 프로그램이 되어 있다. 고객이 쌀, 배추, 생선 등의 생필품을 구매하였 다면 사용속도를 고려하여 고객의 주문이 없더 라도 배달할 수 있게 되었다. 고객이 무엇을 언 제 얼마나 필요로 하는가를 정확하게 파악하는 능력(customer intimacy)을 가지고 고객에게 추천하고 권고할 수 있는 능력을 공급희사가 갖추어야 할 것이다.

\subsection{Total Cost of Usage가 제시되어야 한다.}

시장이 성숙되고 있다. 신규수요가 적어지고 대체 수요와 고급화 수요(upgrade demand)가 증가하고 있다. 단골고객의 비중도 증가하고 있 다. 한 두가지의 상품을 불특정 다수의 고객에 게 판매하던 시대의 수렵형 판매에서 경작형 판매시대로 변화하였다. 소유의 시대에서 사용 의 시대가 되었다고 한다. $\mathrm{CD}$ 를 구입하여 음악 을 즐기는 것보다 좋아하는 음악을 다운(down load)받아서 듣는 것이 더 편리하고 또 비용도 적다. 유행이 빠른 옷도 소유하는 것보다 빌려 입는 것이 더 현명한 선택일 것이다. 큰집을 소 유하는 것보다 필요할 때 빌리는 것이 경제적 인 시대가 되어야 직장과 주거지가 가까운 곳 으로 쉽게 이사할 수 있을 것이다. 가격이 1000 만원인 자동차와 3000 만원인 자동차를 10 년 동 
안 소유하면서 사용한다면 총비용은 각각 얼마 가 될 것인가? 그리고 때와 장소에 맞는 자동 차를 빌려 타는 것과 어느 방법이 더 효율적일 까? China Price와 China Quality와 경쟁하려면 “비싸더라도 싸게 친다”는 상품과 서비스를 개 발하여야 한다.

\subsection{Interactive Communication이 되어야 한다.}

과거에는 고객이 공급자에게 개별적으로 효율 적으로 요구할 수 없었다. 고객의 주문과 요구 에 맞추어 공급하는 것은 극히 제한되어 있었 다. 광고와 판매촉진은 공급자가 불특정 다수의 고객들에게 일방적으로 구매를 자극하는 메시 지의 전달이었다. 마케팅은 고객의 참여를 유발 하는 고객과의 커뮤니케이션이 되어야 한다. 이 제는 고객참여 활동을 활성화함으로써 마케팅 의 성과를 개선할 수 있게 되었다.

\section{Mega-Competition 시대를 맞아 마케팅 공동체가 등장하고 있다.}

대한항공과 아시아나 항공이 경쟁하는 것이 아니라 스카이 팀과 스타 얼라이언스 팀이 경 쟁하고 있다. 롯데의 서울 강남점은 신세계 강 남점이 제휴하고 있는 센트랄 시티와 경쟁하고 있다. 센트랄 시티는 롯데월드와 경쟁하고 있다. 센트랄 시티나 롯데월드에서는 극장, 어린이 놀이시설, 스포츠 센타. 백화점, 식당가 등 여러
종류의 업태가 한곳에 모여 있다. 은행점포에서 도 금융상품 뿐만 아니라 보험, 증권 상품도 판 매하고 있다. 마찬가지로 네트워크를 통하여 고 객이 필요한 모든 것이 복합된 상품을 판매하 는 시대가 되었다. 업종이 달라도 고객만 같다 면 서로 협력하고 있다. 고객의 문제에 대한 해 결방안을 제공하기 위한 이업종 제휴나 업종의 복합화와 응합화가 추진되고 있다. 새로운 경쟁 조직으로서 마케팅 공동체가 성장할 것으로 예 상된다.

표준품을 대중(mass)에게 판매하는 Mass Marketing은 One-to-N Marketing이라 할 수 있다. 양복점과 같이 한 기업이 한 고객에게 맞 춤 상품을 공급한다면 One-to-One Marketing 또는 Customized Marketing이라 한다. 젊은이 들을 위한 이동통신 서비스 상표인 TTL이나 $\mathrm{Na}$ 의 경우 다양한 업태의 이업종들이 결합하여 TTL이나 $\mathrm{Na}$ 회원들에게 제공하고 있다. $\mathrm{M}$ 개의 제휴업체들이 한사람의 고객에게 맞춤서비스를 제공하므로 M-to-One Marketing이라 할 수 있 다. 가상공간에서 고객들의 마케팅 참여활동이 증가함에 따라 마케팅 요소들의 상호관계에 조 직화된 고객의 영향력에 의하여 새롭게 형성될 것으로 기대된다. 고객에게 마케팅 파워를 이양 하면 기업에게는 이익이 돌아오는 마케팅이 구 현될 것이다. Off-Line이나 On-Line에서 고객 을 공유하는 이업종의 공동체가 서로 경쟁하는 시대가 되었다.

〈원고 접수일: 2005. 09. 10〉 〈게재 확정일: 2005, 09, 10〉 